\title{
The evaluation system of green mining based on quantum immune algorithm and neural network
}

\author{
Zhong Dongwang ${ }^{1,}$, , Li Linna ${ }^{1, b}$ \\ ${ }^{1}$ The College of Science, Wuhan University of Science and Technology, Wuhan 430065,China \\ azhongdw123@263.net, ${ }^{b}$ linda020329@163.com
}

Keywords: green mine; quantum algorithms; immune algorithm; neural network

Abstract. The construction of green mine represents the development and utilization level of mineral resources and the sustainable development potential. In view of the characteristics of the large index system and complex evaluation process of green mining, a kind of BP neural network algorithm based on quantum immune apply to green mining evaluation.Because the algorithm combines the space search advantages of immune optimization and those of quantum optimization, it can make the convergence of the neural network training faster, and avoid falling into local optimum.

\section{Introduction}

Mineral resources are the important material base of society survival and development and one of the determinant of country be more prosperous and great, but it is a kind of non-renewable resources.Because of the large population and relatively insufficient resources, our country must implement the strategy of sustainable development in the modernization drive. As a new development model, green mining is the application of the sustainable development strategy in mine construction, and it will apply environmental strategy of overall prevention to the whole process of mine construction and production. At the same time it considers the economic benefits and environmental benefits.

The construction of green mine represents the development and utilization level of mineral resources and the sustainable development potential. Because it focuses on the sustainable development of ecological benefits, economic benefits and social benefits, and gives full consideration to the factors of mineral resources consumption and environmental control, the green mining construction become development and utilization of mineral resources which has higher quality and efficiency, instead of the traditional sense of the development and utilization of mineral resources which destroy the ecological environment and consume the mineral resources. The evaluation of the sustainable development level, namely how to evaluate the health of mine system, is an important research field on green mine construction. Green mining evaluation is comprehensive analysis to the mining economy in the past, present and future, using multidisciplinary, multiple means and various information. Exploring the evaluation method of the green mining is of great significance to realize the level of sustainable development of mining economy in China ${ }^{[1]}$.

\section{the evaluation system of green mining}

\section{The index system of green mining}

We need some specific characteristics to reflect the state of mine sustainable development, namely we must characterize the health by a specific index, so the index system plays an important role of monitor. Based on the in-depth analysis to the connotation of mining sustainable development and the structure of mining system, we can find out all kinds of features which can represent health the level of mine construction development, and finish the quantitative process of the healthy development evaluation of mining. Those provide the necessary basic data for research on the evaluate model.

By the analysis to the connotation and mechanism of mine sustainable development, and following the principle of index system building, the evaluation index system is constituted of the management by law , development and utilization of resources, scientific and technological innovation, environmental protection and social economic, as shown in table 1. 
(1) the target layer: the highest level of the index system, it is the overall goal of health evaluation.

(2) the rule layer: the main system level of the index system, it ensure to realize the overall goal.

(3) the index layer: the most basic level of the index system, it include all specific indicators of health assessment, that are directly measurable factors.

Table 1 The evaluation index system of green mining

\begin{tabular}{|c|c|c|}
\hline target layer & rule layer & index layer \\
\hline \multirow{30}{*}{ 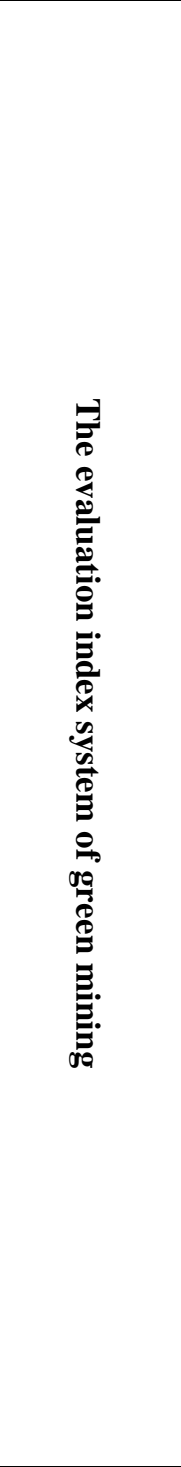 } & \multirow{4}{*}{$\begin{array}{l}\text { management by } \\
\text { law }\end{array}$} & A1 the number of legal license \\
\hline & & A2 the amount of paying taxes and deposit \\
\hline & & A3 the rate of production safety accidents \\
\hline & & A4 the punishment of production safety accident \\
\hline & \multirow{7}{*}{$\begin{array}{l}\text { development and } \\
\text { utilization of } \\
\text { resources }\end{array}$} & B1 impoverishment rate in mining \\
\hline & & B2 recovery percentage \\
\hline & & B3 ore dressing recovery percentage \\
\hline & & B4 tailings utilization \\
\hline & & $\begin{array}{l}\text { B5 comprehensive energy and water consumptio/ten } \\
\text { thousand yuan GDP }\end{array}$ \\
\hline & & $\begin{array}{l}\text { B6 non-renewable energy consumption/ten thousand yuan } \\
\text { GDP }\end{array}$ \\
\hline & & B7 comprehensive utilization rate of mineral resources \\
\hline & \multirow{4}{*}{$\begin{array}{l}\text { scientific and } \\
\text { technological } \\
\text { innovation }\end{array}$} & $\begin{array}{l}\mathrm{C} 1 \text { the proportion of science and technology innovation in } \\
\text { total investment of the mine construction }\end{array}$ \\
\hline & & $\begin{array}{l}\mathrm{C} 2 \text { the proportion of high and new technology of } \\
\text { environmentally friendly technology }\end{array}$ \\
\hline & & C3 number of research reports \\
\hline & & C4 proportion of technical personnel \\
\hline & \multirow{10}{*}{$\begin{array}{l}\text { environmental } \\
\text { protection }\end{array}$} & D1"three simultaneity" system enforced \\
\hline & & D2 water cycle utilization rate \\
\hline & & D3 clean energy utilization \\
\hline & & D4 "three wastes" success rate \\
\hline & & D5 noise pollution \\
\hline & & D6 rate of total discharge of major pollutants reduction \\
\hline & & D7 land reclamation rate \\
\hline & & D8 greening coverage \\
\hline & & D9 geological hazard control rate \\
\hline & & D10proportion of Environmental protection investment \\
\hline & \multirow{5}{*}{ social economic } & E1 social accumulation rate \\
\hline & & E2 social contribution rate \\
\hline & & E3 proportion of indirect employment \\
\hline & & E4 proportion of direct employment \\
\hline & & E5 integrating degree between regions and enterprises \\
\hline
\end{tabular}

\section{data preprocessing of index in the green mining evaluation system}

In the evaluation standard of green mining sustainable development level, the original data is normalized processed by the following method:

Setting $X_{i}=\left(x_{i 1}, x_{i 2}, \mathrm{~L}, x_{i 30}\right)$ to diagnosis index vector, the index data is compressed to the interval $[0,1]$ by using extreme value standardization formula to normalized processing.

$x=\frac{x^{\prime}-x_{\min }^{\prime}}{x_{\max }^{\prime}-x_{\min }^{\prime}}$

$x_{\min }^{\prime}$ is the minimum of evaluation index, $x_{\max }^{\prime}$ is the maximum of evaluation index.

calculation - - the evaluation model basing on quantum immune algorithm and neural network

Neural network can be used in the evaluation and prediction of many practical problems, but it is difficult to convergence in the evaluation system of green mining, because its index system is more complex and large, and the indexes hava inevitably link and overlap.So in this paper, an improved 
algorithm of BP neural network based on quantum immune is put forward used for green mining evaluation. Combining the space search advantages of immune optimization and quantum optimization, the algorithm make the convergence of neural network training faster, and avoid it falling into local optimum ${ }^{[2-4]}$.The implementation steps of algorithm are as follows:

Step1: Generate the initial population: $\mathrm{N}$ quantum antibodies are genenated which compose the initial population groups, where $\mathrm{N}$ is the weights of neural network;

Step2: Construct the fitness function: the error function based on BP neural network construct the chromosome fitness function;

Step3: Select operation: $\mathrm{n}$ antibodies with highest affinity are choosed from groups;

Step4: Cloning augmentation operation: the selected antibodies are expanded based on adaptive quantum revolving door;

Step5: Mutation operation: $m$ antibodies with minimum affinity from population are mutated based on adaptive quantum revolving door;

Step6: Replace operation: the rotation Angles of quantum revolving door are adaptively adjusted, and the quantum antibody population is updated while the quantum gate applies to the probability amplitude all the individuals in the population;

Step7: Return to step 3 to loop compute, until meeting the convergence conditions or reaching the maximum limit of generation.

The neural network model which trained by the above algorithm, can be used in the evaluation system of green mining.

\section{The simulation and the result analysis on the green mining evaluation system}

There are 18 groups of index data applied to the experiments of mining evaluation, then those normalized to the standardization data and shown in table 2.

Each set of data including 30 evaluation indexes, become the input vector, and the green mining evaluation results are the output of network. The evaluation results with value range of $[0,1]$, are provided by experts according to the quantitative level and the scope of each level as shown in table 3, which show in table 4. 
Table 2 the standardization index data of Green mine evaluation system

\begin{tabular}{|c|c|c|c|c|c|c|c|c|c|c|c|c|c|c|c|c|c|}
\hline $\begin{array}{l}\text { target } \\
\text { layer }\end{array}$ & rule layer & $\begin{array}{l}\text { index } \\
\text { layer }\end{array}$ & $\begin{array}{c}\operatorname{mine} \\
1\end{array}$ & $\begin{array}{c}\text { mine } \\
2\end{array}$ & $\begin{array}{c}\text { mine } \\
3\end{array}$ & $\begin{array}{c}\text { mine } \\
4\end{array}$ & $\begin{array}{c}\text { mine } \\
5\end{array}$ & mine & $\begin{array}{c}\operatorname{mine} \\
7\end{array}$ & $\begin{array}{c}\text { mine } \\
8\end{array}$ & $\begin{array}{c}\text { mine } \\
9\end{array}$ & $\begin{array}{c}\text { mine } \\
10\end{array}$ & $\begin{array}{c}\text { mine } \\
11\end{array}$ & $\begin{array}{c}\text { mine } \\
12\end{array}$ & $\begin{array}{c}\text { mine } \\
13\end{array}$ & $\begin{array}{c}\text { mine } \\
14\end{array}$ & $\begin{array}{c}\text { mine } \\
15\end{array}$ \\
\hline \multirow{30}{*}{ 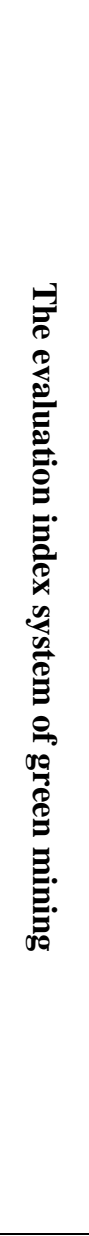 } & \multirow{4}{*}{$\begin{array}{c}\text { Managem-e } \\
\text { nt by law }\end{array}$} & A1 & 0.4 & 0.4 & 0.4 & 0.5 & 0.5 & 0.5 & 0.5 & 0.5 & 0.6 & 0.6 & 0.6 & 0.6 & 0.6 & 0.6 & 0.6 \\
\hline & & $\mathrm{A} 2$ & 0.5 & 0.59 & 0.4 & 0.7 & \begin{tabular}{|l}
0.63 \\
\end{tabular} & 0.8 & 0.76 & \begin{tabular}{|l|l}
0.78 \\
\end{tabular} & 0.9 & \begin{tabular}{|l|}
0.88 \\
\end{tabular} & 0.8 & \begin{tabular}{|l|}
0.85 \\
\end{tabular} & \begin{tabular}{|l|}
0.91 \\
\end{tabular} & 0.9 & 0.96 \\
\hline & & A3 & 0.6 & 0.55 & $\begin{array}{l}0.6 \\
\end{array}$ & 0.4 & 0.45 & 0.4 & 0.4 & \begin{tabular}{|l|}
0.43 \\
\end{tabular} & 0.25 & 0.3 & 0.375 & 0.3 & 0.35 & 0.3 & 0 \\
\hline & & A4 & 0.55 & 0.6 & 0.75 & 0.4 & 0.36 & 0.3 & \begin{tabular}{|l|}
0.37 \\
\end{tabular} & 0.33 & 0 & 0.1 & 0.2 & 0.2 & 0.2 & 0.25 & 0 \\
\hline & \multirow{7}{*}{$\begin{array}{l}\text { Develop-me } \\
\text { nt and } \\
\text { utilization of } \\
\text { resources }\end{array}$} & B1 & 0.55 & 0.55 & 0.6 & 0.5 & 0.4 & 0.2 & 0.5 & 0.3 & 0.15 & \begin{tabular}{|l|}
0.15 \\
\end{tabular} & 0.25 & 0.2 & \begin{tabular}{|l|}
0.15 \\
\end{tabular} & 0.2 & 0.14 \\
\hline & & $\mathrm{B} 2$ & 0.55 & 0.58 & .45 & 0.6 & 0.65 & 0.8 & 0.75 & \begin{tabular}{|l}
0.72 \\
\end{tabular} & 0.78 & 0.8 & 0.76 & \begin{tabular}{|l}
0.88 \\
\end{tabular} & 0.9 & 0.8 & 0.92 \\
\hline & & B3 & 0.55 & 0.59 & 0.5 & 0.6 & \begin{tabular}{|l}
0.63 \\
\end{tabular} & 0.8 & 0.75 & \begin{tabular}{|l}
0.74 \\
\end{tabular} & 0.88 & \begin{tabular}{|l|}
0.85 \\
\end{tabular} & 0.75 & \begin{tabular}{|l|l}
0.89 \\
\end{tabular} & 0.9 & 0.8 & 0.91 \\
\hline & & $\mathrm{B} 4$ & 0.24 & 0.24 & 0.18 & 0.3 & 0.3 & 0.4 & 0.35 & 0.33 & 0.35 & 0.4 & 0.35 & 0.45 & 0.48 & 0.4 & 0.51 \\
\hline & & B5 & 1 & 0.8 & 0.9 & 0.8 & 0.8 & 0.6 & 0.5 & 0.55 & 0.4 & 0.35 & 0.5 & 0.3 & 0.25 & 0.4 & 0.245 \\
\hline & & B6 & 0.55 & 0.52 & 0.65 & 0.5 & 0.45 & 0.4 & 0.4 & 0.42 & 0.39 & \begin{tabular}{|l|}
0.38 \\
\end{tabular} & $\begin{array}{l}0.7 \\
\end{array}$ & 0.35 & 0.3 & 0.35 & 0.25 \\
\hline & & B7 & 0.45 & \begin{tabular}{|l}
0.49 \\
\end{tabular} & 5 & 0.5 & \begin{tabular}{|l}
0.55 \\
\end{tabular} & 0.8 & 0.68 & \begin{tabular}{|l}
0.67 \\
\end{tabular} & 0.72 & \begin{tabular}{|l|}
0.75 \\
\end{tabular} & 7 & 76 & \begin{tabular}{|l|}
0.78 \\
\end{tabular} & 15 & .81 \\
\hline & \multirow{4}{*}{\begin{tabular}{|c} 
scientific \\
and \\
technologica \\
1 innovation
\end{tabular}} & C1 & \begin{tabular}{|l}
0.18 \\
\end{tabular} & \begin{tabular}{|l|l|}
0.19 \\
\end{tabular} & 0.12 & 0.2 & 0.25 & 0.5 & 0.34 & 0.32 & 0.36 & \begin{tabular}{|l|}
0.38 \\
\end{tabular} & 0.35 & 0.4 & 0.45 & 0.4 & 0.52 \\
\hline & & C2 & 0.7 & 0.74 & 0.5 & 0.8 & 0.8 & 0.9 & 0.85 & \begin{tabular}{|l|l|}
0.84 \\
\end{tabular} & 0.85 & 0.88 & 0.85 & 0.9 & 0.94 & 9 & 1 \\
\hline & & C3 & 0.2 & \begin{tabular}{|l|l|} 
\\
\end{tabular} & 0.2 & 0.3 & 0.3 & 0.5 & 0.4 & 0.4 & 0.4 & \begin{tabular}{|l|}
0.44 \\
\end{tabular} & 0.4 & 0.45 & 0.475 & 0.45 & 0.55 \\
\hline & & $\mathrm{C} 4$ & 0.35 & \begin{tabular}{|l|}
0.39 \\
\end{tabular} & 0.25 & 0.4 & 0.4 & 0.7 & 0.6 & 0.55 & 0.6 & \begin{tabular}{|l|}
0.65 \\
\end{tabular} & 0.6 & 0.7 & 0.75 & 0.65 & 0.76 \\
\hline & \multirow{10}{*}{$\begin{array}{l}\text { Environment } \\
\text { al protection }\end{array}$} & D1 & 0.78 & 0.79 & .60 & 0.82 & 0.90 & 0.95 & 0.90 & 0.88 & 0.90 & 0.92 & 0.90 & 0.95 & \begin{tabular}{|l|l}
0.98 \\
\end{tabular} & 95 & .00 \\
\hline & & D2 & 0.74 & 0.74 & 0.65 & \begin{tabular}{|l|} 
\\
\end{tabular} & 0.80 & 0.93 & 0.85 & \begin{tabular}{|l}
0.78 \\
\end{tabular} & 0.85 & \begin{tabular}{|l|}
0.88 \\
\end{tabular} & 0.85 & 0.90 & \begin{tabular}{|l|l|} 
\\
\end{tabular} & 0.90 & 0.96 \\
\hline & & D3 & \begin{tabular}{|l|l|}
0.27 \\
\end{tabular} & \begin{tabular}{|l}
0.30 \\
\end{tabular} & 0.23 & \begin{tabular}{|l|}
0.33 \\
\end{tabular} & 0.47 & 0.60 & \begin{tabular}{|l|}
0.47 \\
\end{tabular} & 0.47 & 0.50 & \begin{tabular}{|l|}
0.53 \\
\end{tabular} & 0.50 & 0.60 & \begin{tabular}{|l|}
0.63 \\
\end{tabular} & 0.60 & 0.73 \\
\hline & & D4 & \begin{tabular}{|l}
0.70 \\
\end{tabular} & \begin{tabular}{|l|l|}
0.79 \\
\end{tabular} & 0.65 & \begin{tabular}{|l|}
0.80 \\
\end{tabular} & 0.85 & 0.95 & 0.90 & \begin{tabular}{|l|l|} 
\\
\end{tabular} & 0.92 & \begin{tabular}{|l|}
0.94 \\
\end{tabular} & 0.90 & \begin{tabular}{|l|}
0.95 \\
\end{tabular} & 0.96 & 0.95 & 1.00 \\
\hline & & D5 & 0.80 & 0.80 & 0.85 & 0.70 & \begin{tabular}{|l}
0.70 \\
\end{tabular} & 0.60 & 0.67 & 0.70 & 0.67 & 0.65 & 0.68 & 0.58 & 0.56 & 0.60 & 0.54 \\
\hline & & D6 & \begin{tabular}{|l}
0.18 \\
\end{tabular} & 0.18 & 0.14 & \begin{tabular}{|l|}
0.23 \\
\end{tabular} & \begin{tabular}{|l}
0.30 \\
\end{tabular} & 0.43 & 0.35 & 0.33 & 0.35 & \begin{tabular}{|l|}
0.38 \\
\end{tabular} & 0.35 & 0.40 & 0.45 & 0 & 0.51 \\
\hline & & D7 & 0.50 & 0.59 & 0.45 & 0.60 & 0.65 & 0.78 & 0.75 & 0.73 & 0.75 & 0.80 & 0.75 & 0.85 & 0.90 & 0.80 & 0.93 \\
\hline & & D8 & 0.40 & 0.49 & 0.40 & 0.60 & 0.55 & 0.78 & 0.65 & 0.60 & 0.70 & 0.75 & 0.80 & 0.78 & 0.80 & 0.75 & 0.81 \\
\hline & & D9 & 0.55 & 0.58 & 0.51 & 0.70 & 0.78 & 0.93 & 0.80 & 0.78 & 0.80 & 0.85 & 0.82 & 0.90 & 0.95 & 0.85 & 1.00 \\
\hline & & D10 & 0.18 & \begin{tabular}{|l|l|}
0.19 \\
\end{tabular} & 0.16 & 0.24 & 0.24 & 0.40 & 0.30 & 0.30 & 0.30 & 0.32 & 0.30 & 0.34 & 0.36 & 0.36 & 0.42 \\
\hline & \multirow{5}{*}{$\begin{array}{c}\text { social } \\
\text { economic }\end{array}$} & E1 & 0.55 & 0.59 & 0.50 & \begin{tabular}{|l|}
0.70 \\
\end{tabular} & 0.65 & 0.89 & 0.75 & 0.71 & 0.75 & \begin{tabular}{|l|}
0.80 \\
\end{tabular} & 0.78 & 0.85 & \begin{tabular}{|l|l|}
0.90 \\
\end{tabular} & 0.80 & 0.91 \\
\hline & & E2 & 0.55 & \begin{tabular}{|l}
0.58 \\
\end{tabular} & 0.40 & \begin{tabular}{|l|}
0.70 \\
\end{tabular} & 0.65 & 0.85 & \begin{tabular}{|l|} 
\\
\end{tabular} & 0.72 & 0.76 & \begin{tabular}{|l|}
0.82 \\
\end{tabular} & 0.75 & 0.88 & 0.85 & 0.80 & 0.91 \\
\hline & & E3 & 0.20 & 0.23 & 0.20 & \begin{tabular}{|l|}
0.30 \\
\end{tabular} & \begin{tabular}{|l}
0.29 \\
\end{tabular} & 0.39 & 0.38 & 0.38 & 0.38 & \begin{tabular}{|l|}
0.39 \\
\end{tabular} & 0.38 & 0.40 & 0.45 & 0.40 & 0.51 \\
\hline & & E4 & \begin{tabular}{|l}
0.18 \\
\end{tabular} & \begin{tabular}{|l|l|} 
\\
\end{tabular} & 0.13 & \begin{tabular}{|l|}
0.30 \\
\end{tabular} & 0.28 & 0.45 & 0.35 & 0.34 & 0.35 & \begin{tabular}{|l|}
0.40 \\
\end{tabular} & 0.35 & 0.38 & 0.45 & 0.40 & 0.53 \\
\hline & & E5 & 0.55 & 0.58 & 0.40 & \begin{tabular}{|l|}
0.70 \\
\end{tabular} & \begin{tabular}{|l}
0.68 \\
\end{tabular} & 0.80 & 0.75 & \begin{tabular}{|l}
0.74 \\
\end{tabular} & \begin{tabular}{|l}
0.78 \\
\end{tabular} & \begin{tabular}{|l|}
0.80 \\
\end{tabular} & 0.75 & \begin{tabular}{|l}
0.82 \\
\end{tabular} & 0.85 & 0.78 & 0.85 \\
\hline
\end{tabular}

According to the sampling data of evaluation of green mining, we can determine that the input layer of the neural network contains 30 neurons and the output layer contains one neuron. Based on many experiments, the number of hidden layer neurons is 20 , and the limit of error and iterations are 0.001 , and 1000 respectively.Considering the performance of the evaluation network, we adopt the stochastic method to generate the training set and the test set, that is, randomly choose 12 samples from the 15 sets of data as training set, the remaining three as test set.

Table 3 the grade of evaluation and signal identification

\begin{tabular}{|c|c|c|c|c|}
\hline grade & First grade & Second grade & Third grade & Forth grade \\
\hline \multirow{2}{*}{ state } & $\begin{array}{c}\text { Green degree is } \\
\text { very strong }\end{array}$ & $\begin{array}{c}\text { Green degree is } \\
\text { stronger }\end{array}$ & $\begin{array}{c}\text { Green degree is } \\
\text { medium }\end{array}$ & $\begin{array}{c}\text { Green degree is } \\
\text { weak }\end{array}$ \\
\hline interval & {$[0.75,1]$} & {$[0.5,0.75)$} & {$[0.25,0.5)$} & {$[0,0.25)$} \\
\hline
\end{tabular}


Table 4 Green mining quantitative evaluation results

\begin{tabular}{|c|c|c|c|c|c|c|c|c|}
\hline $\begin{array}{c}\text { Evaluation } \\
\text { value }\end{array}$ & mine1 & mine 2 & mine 3 & mine 4 & mine 5 & mine 6 & mine 7 & mine 8 \\
\hline grade & $\begin{array}{c}\text { Forth } \\
\text { grade }\end{array}$ & $\begin{array}{c}\text { Forth } \\
\text { grade }\end{array}$ & $\begin{array}{c}\text { Third } \\
\text { grade }\end{array}$ & $\begin{array}{c}\text { Third } \\
\text { grade }\end{array}$ & $\begin{array}{c}\text { Third } \\
\text { grade }\end{array}$ & $\begin{array}{c}\text { Third } \\
\text { grade }\end{array}$ & $\begin{array}{c}\text { Third } \\
\text { grade }\end{array}$ & $\begin{array}{c}\text { Third } \\
\text { grade }\end{array}$ \\
\hline mine 9 & mine 10 & mine 11 & mine 12 & mine 13 & mine 14 & mine 15 & \\
\hline $\begin{array}{c}\text { Evaluation } \\
\text { value }\end{array}$ & 0.62 & 0.63 & 0.62 & 0.65 & 0.7 & 0.71 & 0.78 & \\
\hline grade & $\begin{array}{c}\text { Second } \\
\text { grade }\end{array}$ & $\begin{array}{c}\text { Second } \\
\text { grade }\end{array}$ & $\begin{array}{c}\text { Second } \\
\text { grade }\end{array}$ & $\begin{array}{c}\text { Second } \\
\text { grade }\end{array}$ & $\begin{array}{c}\text { Second } \\
\text { grade }\end{array}$ & $\begin{array}{c}\text { Second } \\
\text { grade }\end{array}$ & $\begin{array}{c}\text { First } \\
\text { grade }\end{array}$ & \\
\hline
\end{tabular}

The simulation hardware environment is Pentium IV / $2.4 \mathrm{GHz} / 512 \mathrm{ram}$, and the simulation software platform are Windows XP operating system and the Matlab 6.5.

After the simulation test, the generalization ability of the network evaluated by the calculation to the deviation of predicted values and the real value in 10 times test, the evaluation results are shown in table 5 .

Table 5 The results of the neural network training 10 times

\begin{tabular}{|c|c|c|c|c|c|c|c|}
\hline \multirow{3}{*}{$\begin{array}{l}\text { Test } \\
\text { times }\end{array}$} & \multicolumn{6}{|c|}{ result } & \multirow{3}{*}{$\begin{array}{l}\text { The } \\
\text { maximum } \\
\text { error of the } \\
\text { evaluation }\end{array}$} \\
\hline & \multicolumn{3}{|c|}{ Quantitative results } & \multicolumn{3}{|c|}{ results of network evaluation } & \\
\hline & Sample 1 & Sample 2 & Sample 3 & Sample 1 & Sample 2 & Sample 3 & \\
\hline 1 & 0.71 & 0.44 & 0.74 & 0.7243 & 0.4449 & 0.7330 & 0.0143 \\
\hline 2 & 0.73 & 0.71 & 0.74 & 0.7332 & 0.7041 & 0.7462 & 0.0062 \\
\hline 3 & 0.65 & 0.70 & 0.78 & 0.6515 & 0.7089 & 0.7996 & 0.0096 \\
\hline 4 & 0.71 & 0.62 & 0.25 & 0.6968 & 0.6205 & 0.2407 & 0.0132 \\
\hline 5 & 0.70 & 0.24 & 0.45 & 0.7148 & 0.2327 & 0.4406 & 0.0148 \\
\hline 6 & 0.25 & 0.75 & 0.43 & 0.2610 & 0.7602 & 0.4192 & 0.0110 \\
\hline 7 & 0.62 & 0.44 & 0.45 & 0.6145 & 0.4377 & 0.4618 & 0.0145 \\
\hline 8 & 0.25 & 0.43 & 0.24 & 0.2591 & 0.4212 & 0.2273 & 0.0127 \\
\hline 9 & 0.62 & 0.70 & 0.71 & 0.6379 & 0.7151 & 0.7054 & 0.0179 \\
\hline 10 & 0.45 & 0.23 & 0.75 & 0.4521 & 0.2463 & 0.7375 & 0.0163 \\
\hline
\end{tabular}

Because the training set and testing set are random, the result of each time will be different. One result is shown in Fig.1, and comparing the evaluation results and the actual data we can see that the neural network model based on quantum immune has faster convergence rate and stronger approximation ability than the BP neural network model . 


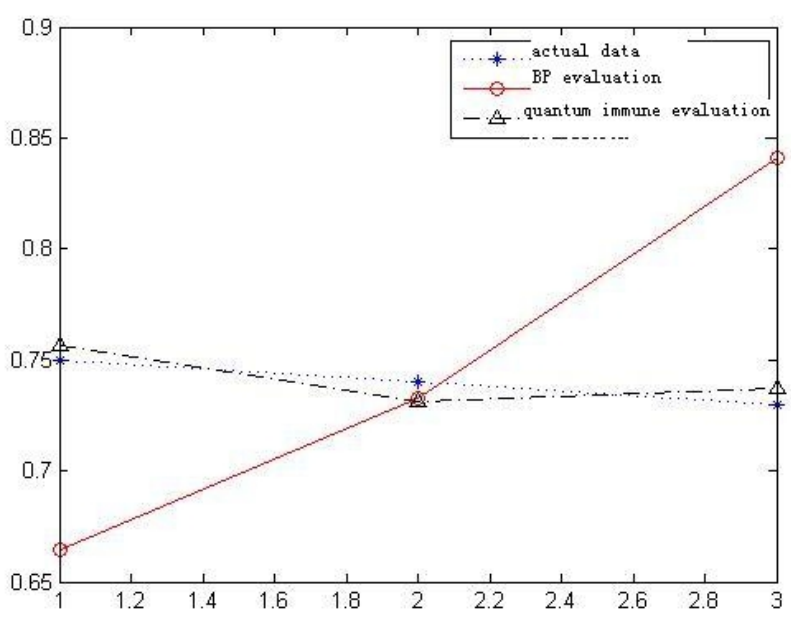

Figure 2 evaluation result contrast of green mining

\section{Conclusion}

Green mining evaluation belongs to the multi-variable, strong coupling and nonlinear prediction problem, and its complex mapping relation make the convergent of conventional algorithm is difficult, so this paper puts forward a comprehensive evaluation based on quantum immune algorithm and neural network, which not only has process mapping ability, but also has the high efficiency of quantum mechanism and global convergence of immune algorithm.

\section{References}

[1] Wang Ruiming. Mining industry sustainable development mode study. Journal of coal technology, 2007, 26 (9) ,p1-3.

[2] Zuo Xingquan, Li Shiyong. Optimal design of radial basis function fuzzy neural network controlled based on immune evolutionary algorithm. Control theory \& applications, 2004,21(4),p521-525.

[3] Hou Jiali, Zhu Meiji, Peng Hong. Research on Modular-based immune neural network model.Acta electronic sinica, 2005,33(8),p1502-1505.

[4] Li Yangyang, Jiao Licheng. Quantum-inspired immune clonal algoriithm for SAT Problem.Chinese journal of computers,2007,30(2),p176-183. 